\title{
Úvodem
}

\section{Jana Dlouhá}

\author{
Envigogika 9 (2) - Úvodník/ Editorial
}

Publikováno/Published 31. 10. 2014

DOI: $\underline{10.14712 / 18023061.458}$

Vážení čtenáři a př́znivci Envigogiky,

Letos se toho $v$ naší sféře vzdělávání děje více, než stíháme zaznamenávat, a tak soustavně řešíme problém, zda do dění vstupovat či jej popisovat. Přinášíme-li záznamy o tomto dění, jsou kusé a opožděné; často jsou pouhými výkřiky tonoucího v moři událostí a informací. Mnohdy se nedaří sladit naši snahu situaci mapovat a současně poskytovat dobré podklady (texty) pro její reflexi, analýzu či transformaci. Alespoň vám však můžeme potvrdit, že jsme stále ještě zde, byt ve vlnách a často jimi smýkáni do nepředvídaných směrů. A právě $z$ této nakloněné paluby přinášíme nové podzimní číslo Envigogiky.

Co $v$ něm najdete zajímavého? Začneme tím, co se pro svou kontroverzní povahu nevešlo do recenzované rubriky, a představuje tak "pouhý" námět k diskusi. Mojmír Vlašín se zamýšlí nad tím, co by $v$ dnešní krajině ( $a$ při péči o ni) mělo hrát větší roli - z různých hledisek rozebírá, jak spolu souvisí estetika a biodiverzita. Ukazuje se zde, jak zažitá představa přírody coby ztělesněné ( $a$ vyjádřené) harmonie může vést $k$ nepochopení jejích principů, zvláště pokud se nezamyslíme nad tím co (a proč) je na ní krásné. A zase naopak, její přirozené krize či konflikty, jež se často ukazují navenek "neesteticky", mohou mít za následek podobný nesoulad i ve sféře sociální. Takže pak můžeme být postaveni před skutečnou nutnost volby - estetika či biodiverzita? Druhou stranou podobných úvah může být text Ivany Hermové (Růžičkové), který zvláštním způsobem exponuje význam místa pro utváření lidské identity. Ve srovnání těchto dvou výpovědí se projevuje bezmoc (vůči nároku vytěžit, ekonomicky zhodnotit...), ale také silná potřeba zachování toho, co je původní, autentické, třebaže $v$ tomto prípadě prošlo proměnou $v$ čisté vztahy a emoce, a ve skutečnosti neexistuje. Jak ovšem $v$ praxi skutečnou krajinu bránit, usilovat o zachování krásy, ale i prostého bytí jejích součástí, dokládá Vendula Záhumenská. Na príkladu území Na Plachtě v Hradci Králové uvádí možnosti, které má veřejnost při (spolu)rozhodování o svém nejbližším okolí nebo ovlivňování činnosti veřejné správy.

Další dva texty recenzované rubriky se zabývají otázkou, jak reálný svět prírody, prípadně i s jejími „krizemi", jimiž zákonitě nebo přičiněním člověka prochází, proměnit v učivo. Článek Markéty Pluháčkové naznačuje, jak je v projektové výuce možno uchopit téma environmentálních rizik. S jeho pomocí pak Ize rozvíjet obecné znalosti o souvisejících (přírodních) procesech probíhajících na lokální úrovni, ale také upozorňovat na možnosti praktické ochrany a dlouhodobé prevence. Na př́ikladu uskutečněné výuky tohoto typu ukazuje autorka, jak pracovat s aplikací Google Earth, využívat teoretické znalosti při terénním vyučování; součástí je i vyhodnocení výsledků. Poslední text recenzované rubriky (Analýza aktuálních kompetencí žáků a studentů...) připomíná dovednosti téměř zapomenuté (a to i při diskusích o environmentálním vzdělávání): tradiční schopnost pozorovat a popisovat prírodu 
a její obyvatele. Jan Andreska a Kateřina Švecová v něm zkoumají úspěšnost při poznávání našich běžných druhů obratlovců (ryb, obojživelníků, plazů, ptáků a savců) žáky základních a středních škol, a své výsledky porovnávají s obdobnou studií provedenou před 45 lety.

To se už dostáváme ke zprávám o současném dění, které - jak jsme zmínili výše bude mít vliv nejen na oblast naší práce, ale ovlivňuje významně už ted'i nás samotné. Píše o něm Eduard Petiška; v zaujatém záznamu diskuzního semináře Společnosti pro trvale udržitelný život představuje obnovenou Radu vlády pro udržitelný rozvoj. Přehled její současné činnosti i předpokládaných aktivit do budoucna, který je součástí textu, naznačuje, že by tato nově se rodící instituce mohla být nadějí i pro oblast vzdělávání. Jinou podobu semináře, který organizovala Rada vlády pro udržitelný rozvoj, představuje Beáta Binková - v jejím textu se dozvíme, jak podpořit podnikání $v$ ČR pomocí finanční spoluúčasti zaměstnanců. Důležité téma právě končící Dekády vzdělávání pro udržitelný rozvoj a jejích závěrů i možností pokračovat $v$ započaté práci přináší další text nerecenzované rubriky Informace. Dekáda VUR byla slavnostně uzavřena na Světové konferenci UNESCO v japonském městě Nagoya $v$ listopadu tohoto roku; byl zde současně přijat program na přšší pětileté období (Globální akční program). Našim čtenářům předkládáme přehled výsledků Konference $\mathrm{i}$ stručné zhodnocení (spíše nevyužitých) možností České republiky při zapojování do tohoto celosvětového dění.

Mapujeme i další letošní události, kterými se pomalu utváří náš malý svět založený na hodnotách udržitelnosti. Začátkem června byla udělena cena Josefa Vavrouška za rok 2013, a my ted' nabízíme dva z projevů přednesených v rámci tohoto slavnostního aktu. Jan Kára se ve vzpomínce na svého kolegu a prítele Josefa Vavrouška pokouší s jeho odkazem vyrovnat osobně; ve zpětném pohledu se teprve potvrzují i ty Vavrouškovy názory a vize do budoucna, které se ve své době zdály nemožné a neuskutečnitelné. Laudatio na letos oceněného Petra Pakostu $z$ "pera" Martina Říhy pak mapuje nejdůležitější události života oslavence $v$ souvislostech jeho společenských aktivit; dozvídáme se tak mnoho zajímavého o historii protestů proti těžbě hnědého uhlí v Severočeském regionu i záchraně zámku Jezeří. Nakonec se Mikuláš Huba zpovídá ze svých zážitků z expedice do Peru, kterou navštívil letos $\checkmark$ červnu jako člen mezinárodního týmu v rámci projektu Od nadspotřeby $k$ solidaritě. $\vee$ textu se dostaneme i k místním environmentálním otázkám, napríklad jak se obyvatelstvo této země staví k těžbě zlata nebo kácení tropických pralesů.

A to je pro tentokrát téměř vše, máme pro vás připraven též překlad textu o environmentálním vzdělávání z časopisu Science, $v$ tuto chvíli ale čekáme na povolení $\mathrm{k}$ jeho publikaci.

Krásný čas adventu svým čtenářům přeje

Jana Dlouhá za redakci Envigogiky 